\title{
FAKTOR-FAKTOR YANG BERHUBUNGAN DENGAN KEMANDIRIAN PETANI DALAM PENGAMBILAN KEPUTUSAN USAHATANI DI KSM JAYA AMANAH, KABUPATEN BANDUNG
}

\section{FACTORS RELATED TO FARMER'S INDEPENDENCE IN FARMING DECISION MAKING IN THE KSM JAYA AMANAH, BANDUNG REGENCY}

\author{
Dhyna Dellaura Pujakesuma*, Tuti Karyani \\ Program Studi Agribisnis Fakultas Pertanian Universitas Padjadjaran \\ Jl. Raya Jatinangor Sumedang Km, 21 \\ Email: dhynadellaura@gmail.com \\ (Diterima 02-07-2020; Disetujui 23-07-2020)
}

\begin{abstract}
ABSTRAK
Pertanian Indonesia tidak luput dari masalah permodalan sehingga petani masih bergantung kepada rentenir dan tengkulak serta bergantung kepada bantuan dari pemerintah. Pembiayaan syariah yang diterapkan oleh KSM Jaya Amanah dengan pendayagunaan dana ZISWAF bertujuan untuk pemberdayaan masyarakat sehingga akan menciptakan pemahaman serta kesadaran sikap dan prilaku menuju perilaku hidup mandiri. Penelitian ini bertujuan untuk menganalisis faktor-faktor yang berhubungan dengan kemandirian petani dalam pengambilan keputusan usahatani. Desain penelitian yang digunakan adalah kuantitatif dengan teknik sensus. Metode analisis data yang digunakan adalah analisis statistik deskriptif dan uji Rank Spearman. Hasil penelitian menunjukkan, kemandirian petani anggota KSM Jaya Amanah dalam pengambilan keputusan usahatani tergolong sedang. Adapun faktor-faktor yang berhubungan dengan kemandirian petani dalam pengambilan keputusan usahatani adalah usia, jenis kelamin, pengalaman berusahatani, ketersediaan informasi, dan ketersediaan sarana dan prasarana.
\end{abstract}

Kata Kunci: Pembiayaan, ZISWAF (Zakat, Infak, Sedekah, Wakaf), Kemandirian Petani

\section{ABSTRACT}

Indonesian agriculture is not free from capital problems so farmers still depend on moneylenders, middlemen, and government assistance. Islamic financing implemented by KSM Jaya Amanah by utilizing ZISWAF funds is aimed to empowering the community so it will improve the attitudes and behavior of each individuals and groups to become independent. This study aims to analyze the factors related to the independence of farmers in farm decision making. This research used quantitative research design with a census techniques. The method that is used for data analysis is descriptive statistical analysis and Spearman's Rank test. The results showed that the independency of farmers of KSM Jaya Amanah in farm decision making is classified as moderate. The factors related to the independence of farmers in farm decision making are age, sex, farming experience, information's availability and availability of facilities and infrastructure.

Keywords: Financing, ZISWAF (Zakat, Infak, Sedekah, Wakaf), Farmer's Independence

\section{PENDAHULUAN}

Indonesia memiliki sektor yang berfungsi ideal, yakni sektor pertanian yang menjadi sumber lapangan pekerjaan dengan jumlah yang cukup besar (Widyawati, 2017). Sektor pertanian juga masih berkontribusi besar terhadap distribusi Produk Domestik Bruto Indonesia dalam 4 tahun terakhir, yakni 
berada pada urutan ke dua di bawah industri pengolahan yang terlihat dari Tabel 1.

Tabel 1. Distribusi PDB Indonesia Tahun 2015-2018 (Persen)

\begin{tabular}{|c|c|c|c|c|c|}
\hline No & $\begin{array}{l}\text { Sektor } \\
\text { Ekonomi }\end{array}$ & 2015 & 2016 & 2017 & 2018 \\
\hline 1 & $\begin{array}{l}\text { Industri } \\
\text { Pengolahan }\end{array}$ & 20,99 & 20,52 & 20,16 & 19,86 \\
\hline 2 & $\begin{array}{l}\text { Pertanian, } \\
\text { Kehutanan, } \\
\text { dan } \\
\text { Perikanan }\end{array}$ & 13,49 & 13,48 & 13.15 & 13,02 \\
\hline 3 & $\begin{array}{l}\text { Perdagangan } \\
\text { dan Reparasi }\end{array}$ & 13,30 & 13.19 & 13.02 & 12,81 \\
\hline 4 & Konstruksi & 10,21 & 10,38 & 10,38 & 10,53 \\
\hline 5 & Lain-lain & 42,01 & 42,43 & 43,29 & 43,78 \\
\hline
\end{tabular}

Posisi strategis sektor pertanian tidak luput dari hambatan dan permasalahan, khususnya masalah permodalan (Nasution, 2016). Pembiayaan dalam sektor pertanian masih dinilai kurang efekif dikarenakan oleh berbagai hal seperti penetapan bunga yang memberatkan petani, antara debitur dan kreditur terjadi kesenjangan, pembiayaan dari perbankan lebih banyak memilih sektor nonpertanian, serta jumlah kredit yang diberikan kepada sektor lain lebih tinggi dibandingkan sektor pertanian.

Tabel 2. Persentase Konsentrasi Kredit, Kredit Bank Perkreditan Rakyat (BPR), Pembiayaan Bank Syariah, dan Pembiayaan Bank Perkreditan Rakyat Syari'ah (BPRS) Nasional Tahun 2018 berdasarkan Sektor Ekonomi

\begin{tabular}{clcccc}
\hline \multirow{2}{*}{ No } & \multicolumn{1}{c}{ Sektor Ekonomi } & $\begin{array}{c}\text { Konsentrasi } \\
\text { Kredit }\end{array}$ & $\begin{array}{c}\text { Kredit } \\
\text { BPR }\end{array}$ & $\begin{array}{c}\text { Pembiayaan } \\
\text { Bank Syariah }\end{array}$ & $\begin{array}{c}\text { Pembiayaan } \\
\text { BPRS }\end{array}$ \\
\hline 1 & Sektor Industri Pengolahan & 16,97 & 1,44 & 7,77 & 1,07 \\
2 & Sektor Perdagangan Besar dan Eceran & 18,70 & 25,44 & 11,16 & 22,56 \\
3 & Pertanian, Kehutanan, Perikanan & 6,96 & 5,84 & 4,04 & 4,43 \\
4 & Konstruksi & 5,57 & 3,20 & 7,47 & 7,52 \\
5 & Pertambangan dan Penggalian & 2,28 & 0,25 & 1,88 & 0,21 \\
\hline
\end{tabular}

Sumber: Statistik Perbankan Syariah (SPS) Juni 2018

Berdasarkan Tabel 2 dapat dilihat bahwa persentase kredit, kredit BPR, pembiayaan Bank Syari'ah, serta pembiayaan BPRS pada tingkat nasional untuk sektor pertanian jauh lebih rendah jika dibandingkan dengan sektor industri pengolahan dan sektor perdagangan. Kenyataannya petani memiliki pola penerimaan dan pengeluaran yang tidak seimbang. Pendapatan petani hanya diperoleh pada setiap musim panen, sementara pengeluarannya selalu ada setiap hari untuk memenuhi kebutuhan sehari-hari. Jika kebutuhan mendesak, petani terpaksa meminjam kepada tengkulak karena prosesnya yang cepat dan tanpa persyaratan sulit, sedangkan jika meminjam kepada lembaga keuangan harus melalui prosedur yang panjang serta disetai agunan (Saragih, 2017). Solusi yang diperlukan sebagai alternatif pembiayaan bagi permodalan pertanian yang mulai dimanfaatkan dalam beberapa tahun terakhir ini adalah 
pembiayaan syariah. Indonesia merupakan negara yang berpotensi dalam mengembangkan pembiayaan syariah karena penduduk Indonesia yang mayoritas menganut agama Islam. Berdasarkan data dari global religius futures tahun 2019, memprediksi bahwa pada tahun 2050 bahwa 256.000.000 jiwa dari penduduk Indonesia adalah beragama Islam dimana jumlahnya jauh lebih banyak dibandingkan yang beragama nasrani yakni 33.000.000 jiwa.

Pembiayaan syariah berfungsi menyalurkan dana yang telah terkumpul kepada masyarakat salah satunya melalui Lembaga Amil Zakat (LAZ) yang merupakan lembaga pembiayaan syariah bersifat nonprofit dan lebih berorientasi pada pemberdayaan masyarakat (Hisamuddin, 2017). LAZ memiliki potensi dalam peningkatan kesejahteraan dan kemandirian masyarakat baik dari segi pendidikan, kesehatan, pendapatan, serta dapat bekerja sama dengan pemerintah dalam mewujudkannya. LAZ Al-Azhar merupakan salah satu Lembaga Amil Zakat yang telah berkembang di Indonesia dan juga menjalin kerjasama dengan Kelompok Swadaya Masyarakat (KSM) Jaya Amanah yang berada di Desa Mekarkaya, Kecamatan Pacet, Kabupaten Bandung. Mayoritas penduduk di Kecamatan Pacet bekerja pada bidang pertanian meliputi tanaman bahan makanan (palawija, hortikultura), perkebunan, peternakan, perikanan, kehutanan, dan buruh tani.

Masalah permodalan masih dirasakan oleh petani di Desa Mekarjaya seperti sulitnya mendapatkan modal, terutama dari perbankan. Jarak dari desa menuju bank lebih kurang $2 \mathrm{~km}$, akses pinjaman dari bank cukup sulit karena petani harus memiliki jaminan atau agunan. Permodalan yang sulit menyebabkan petani masih bergantung pada tengkulak dan masih menerapkan sistem ijon. Akibatnya petani sulit untuk mendapatkan keuntungan sehingga pendapatan pun sulit untuk meningkat. Permasalahan permodalan tersebut mulai terbantu berkat adanya bantuan dari KSM Jaya Amanah. Persentase penerima dana ZISWAF di KSM Jaya Amanah dapat dilihat dari Tabel 3.

Tabel 3. Persentase Pekerjaan Penerima Dana Zakat, Infaq, Sedekah, Wakaf (ZISWAF) KSM Jaya Amanah

\begin{tabular}{|c|c|c|}
\hline No & Pekerjaan & Jumlah ( \%) \\
\hline 1 & Petani & $45 \%$ \\
\hline 2 & Peternak & $35 \%$ \\
\hline 3 & Buruh & $5 \%$ \\
\hline 4 & Pedagang (swasta) & $10 \%$ \\
\hline 5 & Lain Lain & $5 \%$ \\
\hline & Total & $100 \%$ \\
\hline
\end{tabular}

Sumber: KSM Jaya Amanah 
Berdasarkan Tabel 3, penyaluran dana ZISWAF terbesar diberikan kepada petani dikarenakan mayoritas anggota KSM Jaya Amanah berprofesi sebagai petani. Penyaluran dana zakat merupakan bentuk pendayagunaan dana zakat yang bertujuan untuk melakukan pemberdayaan. Pemberdayaan ini dilaksanakan dengan berbagai program sehingga diharapkan bisa memberi dampak yang positif terhadap masyarakat. Adanya pendayagunaan zakat akan menciptakan pemahaman serta kesadaran masyarakat sehingga sikap dan perilaku akan terbentuk menuju perilaku hidup mandiri (Khasanah, 2010).

Menurut Ibrahim (2001), dalam mengambil keputusan untuk berusahatani, kemandirian petani masih relatif rendah. Penyebabnya adalah budaya ketergantungan petani pada pemerintah yang melakukan pembangunan pertanian hanya dengan penyediaan kebutuhan seperti seperti bibit, pupuk, dan pestisida tanpa adanya pemberdayaan. Sejalan dengan hal tersebut, pemberdayaan yang dilakukan oleh KSM Jaya Amanah melalui pendayagunaan dana ZISWAF diharapkan mampu meningkatkan kemandirian petani dalam pengambilan keputusan untuk kegiatan usahataninya.
Oleh karena itu, peneliti tertarik untuk melakukan penelitian mengenai "Faktor-faktor yang Berhubungan dengan Kemandirian Petani dalam Pengambilan Keputusan Usahatani di KSM Jaya Amanah, Desa Mekarjaya, Kabupaten Bandung”

\section{METODE PENELITIAN}

Penelitian ini telah dilaksanakan di KSM Jaya Amanah, Desa Mekarjaya, Kabupaten Bandung pada Januari-Maret 2020. Desain penelitian ini adalah kuantitatif dengan teknik sensus, yakni suatu penelitian yang dilakukan terhadap seluruh anggota pupulasi jika jumlah populasi kurang dari 100 orang (Arikunto, 2012). Pengambilan responden dilakukan kepada seluruh dari populasi yakni 54 petani anggota KSM Jaya Amanah. Teknik pengumpulan data yang dilakukan adalah dengan observasi, wawancara, kuesioner, serta studi kepustakaan. Jenis data yang diperoleh terdiri dari data demografi dan data persepsi. Data demografi seperti umur, jenis kelamin, pendidikan formal, jumlah tanggungan keluarga, pengalaman berusahatani, keaktifan mencari informasi, dan luas penguasaan lahan pertanian. Data persepsi yakni pernyataan responden mengenai faktor eksternal 
yang diduga berhubungan dengan kemandirian petani dalam pengambilan keputusan usahatani, kemudian pernyataan responden mengenai aspekaspek kemandirian petani dalam pengambilan keputusan usahatani yang terdiri dari manajemen permodalan, proses produksi, dan pemasaran hasil.

Uji instrumen penelitian menggunakan uji validitas dan uji reliabilitas. Hasil uji validitas item per butir kuesioner didapatkan 32 item kuesioner dinyatakan valid. Hasil uji reliabilitas menunjukkan item kuesioner cukup reliabel hingga reliabel. Selanjutnya untuk menganalisis data dalam melihat faktor-faktor yang berhubungan dengan kemandirian petani dalam pengambilan keputusan usahatani menggunakan uji statistik korelasi Rank Spearman sehingga dapat terlihat ada atau tidaknya hubungan dari dua variabel berskala ordinal.

\section{HASIL DAN PEMBAHASAN}

KSM Jaya Amanah memiliki program pemberdayaan ekonomi dalam meningkatkan kesejahteraan masyarakat dan pengentasan kemiskinan, yaitu; 1) Program Rumah Pembiayaan Pertanian (RPP); 2) Kelompok Usaha Bersama (KUB) Peternak; 3) KUB UMKM.
Untuk menganalisis faktor-faktor yang berhubungan dengan kemandirian petani anggota KSM Jaya Amanah dalam pengambilan keputusan usahatani, maka dilakukan tahap-tahap sebagai berikut:

1. Pertanyaan dalam kuesioner terdiri dari jawaban pilihan ganda yang diurutkan dengan skala likert 1, 2, 3, 4

2. Mengkategorikan data skala ordinal berdasarkan penghitungan dari nilai tengan dan standar deviasi sebagai berikut (Arikunto, 2012):

- Tinggi $=$ skor lebih besar atau sama dari skor rata-rata ditambah standar deviasi $(\mathrm{x} \geq \mathrm{M}+1 \mathrm{SD})$

- Sedang = skor lebih besar atau sama dari skor rata-rata dikurang standar deviasi dan lebih kecil dari skor rata-rata ditambah standar deviasi $(\mathrm{M}-\mathrm{SD} \leq \mathrm{x}<\mathrm{M}+\mathrm{SD})$

- Rendah $=$ skor lebih kecil dari skor rata-rata dikurang standar deviasi $(\mathrm{x}<\mathrm{M}-\mathrm{SD})$

$$
\begin{aligned}
M & =\frac{x \text { maks }+x \min }{2} \\
S D & =\frac{x \text { maks }-x \min }{6}
\end{aligned}
$$

Keterangan:

$$
\begin{aligned}
& \text { x maks = skor tertinggi } \\
& \text { x min = skor terendah } \\
& M=\text { skor rata-rata } \\
& \mathrm{SD}=\text { standar deviasi }
\end{aligned}
$$


Tabel 4. Pengkategorian Variabel Berdasarkan Sebaran Data

\begin{tabular}{|c|c|c|c|c|c|c|c|c|}
\hline \multirow{2}{*}{ No } & \multirow{2}{*}{ Variabel } & \multirow{2}{*}{ X Maks } & \multirow{2}{*}{$\begin{array}{c}X \\
\text { Min }\end{array}$} & \multirow{2}{*}{ Mean } & \multirow{2}{*}{$\begin{array}{l}\text { Standar } \\
\text { Deviasi }\end{array}$} & \multicolumn{3}{|c|}{ Kategori } \\
\hline & & & & & & Rendah & Sedang & Tinggi \\
\hline \multicolumn{9}{|c|}{ Faktor Internal } \\
\hline 1 & Umur & 23 & 73 & 48,5 & 8,5 & $<40$ & $40-56$ & $>56$ \\
\hline 2 & Pendidikan & 16 & 0 & 8 & 16 & $<5$ & $5-10$ & $>10$ \\
\hline 3 & $\begin{array}{l}\text { Jumlah Tanggungan } \\
\text { Keluarga }\end{array}$ & 8 & 2 & 5 & 1 & $<4$ & $4-5$ & $>5$ \\
\hline 4 & $\begin{array}{l}\text { Pengalaman } \\
\text { Berusahatani }\end{array}$ & 50 & 1 & 25,5 & 8,16 & $<17$ & $17-33$ & $>33$ \\
\hline 5 & $\begin{array}{l}\text { Keaktifan Mencari } \\
\text { Informasi }\end{array}$ & 3 & 1 & 2 & 0,3 & $<1,7$ & $1,7-2,2$ & $>2,2$ \\
\hline 6 & Luas Lahan & 1 & 0,03 & 0,5 & 0,1 & $<0,4$ & $0,4-0,6$ & $>0,6$ \\
\hline \multicolumn{9}{|c|}{ Faktor Eksternal } \\
\hline 1 & $\begin{array}{l}\text { Dukungan KSM Jaya } \\
\text { Amanah }\end{array}$ & 23 & 5 & 14 & 3 & $<11$ & $11-16$ & $>16$ \\
\hline 2 & $\begin{array}{l}\text { Ketersediaan } \\
\text { Informasi }\end{array}$ & 9 & 3 & 6 & 1 & $<5$ & $5-6$ & $>6$ \\
\hline 3 & $\begin{array}{l}\text { Ketersediaan Sarana } \\
\text { Prasarana }\end{array}$ & 18 & 6 & 12 & 2 & $<10$ & $10-13$ & $>13$ \\
\hline \multicolumn{9}{|c|}{ Kemandirian Petani dalam Pengambilan Keputusan Usahatani } \\
\hline 1 & $\begin{array}{l}\text { Manajemen } \\
\text { Permodalan }\end{array}$ & 9 & 3 & 6 & 1 & $<5$ & $5-6$ & $>6$ \\
\hline 2 & Proses Produksi & 24 & 8 & 16 & 2,7 & $<13$ & $13-17$ & $>17$ \\
\hline 3 & Pemasaran Hasil & 9 & 3 & 6 & 1 & $<5$ & $5-6$ & $>6$ \\
\hline 4 & Kemandirian Total & 42 & 14 & 28 & 4,67 & $<23$ & $23-31$ & $>31$ \\
\hline
\end{tabular}

\section{Faktor Internal}

Faktor Internal adalah suatu ciri atau karakteristik yang asalnya dari diri seorang petani dan ada dugaan bahwa faktor ini erat hubungannya dengan semua aspek kehidupan seperti kemandirian petani dalam melaksanakan kegiatan usahatani (Aminudin, 2014). Berdasarkan sebaran data menurut kategori nilai tengah serta simpangan baku, maka didapatkan data sebagai berikut:

\section{Usia}

Persentase paling rendah adalah petani dengan usia dibawah 40 tahun, padahal petani yang berumur muda lebih termotivasi, inovatif dan berani mengambil risiko dibandingkan dengan petani yang berumur lebih tua (Musafiri, 2016). Sedikitnya jumlah petani yang berusia kecil dari 40 tahun menunjukkan masih terbatasnya golongan muda yang bekerja di sektor pertanian di pedesaan.

\section{Jenis Kelamin}

Petani berjenis kelamin perempuan lebih sedikit jika dibandingkan petani berjenis kelamin laki-laki, karena kegiatan usahatani lebih banyak membutuhkan tenaga laki-laki seperti pengolahan lahan, penanaman, pemeliharaan, pemupukan, pengairan, panen, serta kegiatan fisik lainnya. 
Sejalan dengan penelitian Sudalmi (2009) yang menyatakan bahwa dalam usahatani padi sawah, tenaga kerja pria lebih dominan digunakan dibandingkan dengan tenaga kerja wanita.

Tabel 5. Faktor Internal

\begin{tabular}{|c|c|c|c|}
\hline No & Variabel & Kategori & 'ersen (\%) \\
\hline \multirow{3}{*}{1} & \multirow{3}{*}{ Usia } & $\begin{array}{l}\text { rendah } \\
(<40 \text { tahun })\end{array}$ & $30 \%$ \\
\hline & & $\begin{array}{l}\text { sedang } \\
\text { (40-56 tahun) }\end{array}$ & $44 \%$ \\
\hline & & $\begin{array}{l}\text { tinggi } \\
\text { (>56 tahun) }\end{array}$ & $26 \%$ \\
\hline \multirow{2}{*}{2} & Jenis & perempuan (1) & $26 \%$ \\
\hline & Kelamin & laki-laki (2) & $74 \%$ \\
\hline \multirow{3}{*}{3} & \multirow{3}{*}{ Pendidikan } & $\begin{array}{l}\text { rendah } \\
(<5 \text { tahun })\end{array}$ & $61 \%$ \\
\hline & & $\begin{array}{l}\text { sedang } \\
\text { (5-10 tahun) }\end{array}$ & $26 \%$ \\
\hline & & $\begin{array}{l}\text { tinggi } \\
(>10 \text { tahun })\end{array}$ & $13 \%$ \\
\hline \multirow{3}{*}{4} & Jumlah & rendah $(<4)$ & $30 \%$ \\
\hline & Tanggungan & sedang (4-5) & $50 \%$ \\
\hline & Keluarga & tinggi $(>5)$ & $20 \%$ \\
\hline \multirow{3}{*}{5} & \multirow{3}{*}{$\begin{array}{l}\text { Pengalaman } \\
\text { Berusahatani }\end{array}$} & $\begin{array}{l}\text { rendah } \\
(<17 \text { tahun })\end{array}$ & $50 \%$ \\
\hline & & $\begin{array}{l}\text { sedang } \\
\text { (17-33 tahun) }\end{array}$ & $43 \%$ \\
\hline & & $\begin{array}{l}\text { tinggi } \\
\text { (>33 tahun) }\end{array}$ & $7 \%$ \\
\hline \multirow{3}{*}{6} & Keaktifan & rendah $(<1,7)$ & $0 \%$ \\
\hline & Mencari & sedang $(1,7-2,2)$ & $28 \%$ \\
\hline & Informasi & tinggi $(>2,2)$ & $72 \%$ \\
\hline \multirow{3}{*}{7} & \multirow{3}{*}{ Luas Lahan } & rendah $(<0,4)$ & $85,2 \%$ \\
\hline & & sedang $(0,4-0,6)$ & $7,4 \%$ \\
\hline & & tinggi $(>0,6)$ & $7,4 \%$ \\
\hline
\end{tabular}

\section{Pendidikan}

Tingkat pendidikan petani umumnya tergolong rendah atau dapat dikatakan sebagian besar petani hanya menempuh pendidikan hingga SD. Penyebabnya adalah terbatasnya biaya dan juga kurangnya perhatian terhadap dunia pendidikan. Kenyataannya, pendidikan merupakan usaha seseorang membekali dirinya dengan ilmu agar secara mandiri ia mampu untuk mengatasi masalahnya.

\section{Jumlah Tanggungan Keluarga}

Umumnya keluarga yang utuh terdiri dari suami, istri, dan anaknya. Adapun jumlah tanggungan keluarga petani termasuk kategori sedang berkisar dari 2 hingga 8, yakni responden sendiri, istri, dan anak. Yasin dan Ahmad (2008) menyebutkan, tanggungan keluarga yang ditanggung kepala keluarga dapat menambah kebutuhan hidup keluarga, maka petani harus meningkatkan produktivitas usahatani agar dapat memenuhi kebutuhan keluarga.

\section{Pengalaman Berusahatani}

Pengalaman petani dalam berusahatani berkisar antara 1 hingga 50 tahun, dengan rata-rata 25,5 tahun dimana setengah dari petani dikategorikan rendah dan setengahnya lagi sedang sampai lama. Petani anggota KSM Jaya Amanah sudah berpengalaman relatif cukup lama dalam berprofesi sebagai petani. Pengetahuan bertani didapatkan secara turun temurun dari orang tua petani, akibatnya teknik-teknik yang digunakan tidak akan berbeda jauh dengan orang tua nya dahulu. 


\section{Keaktifan Mencari Informasi}

Keaktifan mencari informasi petani umumnya berada pada kategori tinggi. Petani anggota KSM Jaya Amanah aktif mencari informasi usahatani melalui Saung Ilmu yang menjadi pusat berkumpulnya para petani untuk berkumpul dan bertukar informasi. Ratarata petani anggota selalu mengikuti kegiatan rutin satu kali dalam satu bulan di Saung Ilmu kemudian diluar kegiatan rutinan tersebut juga sering bermusyawarah. Ratnasari, dkk (2012) mengungkapkan, persepsi petani terhadap suatu inovasi ditentukan oleh informasi yang didapatkan petani.

\section{Luas Penguasaan Lahan}

Luas lahan petani umumnya berada pada kategori rendah yakni kurang dari 0,4 ha. Luas penguasaan lahan yang kurang dari 0,4 hektar disebabkan masih rendahnya perekonomian petani sehingga belum mampu untuk membeli lahan lebih luas lagi, kemudian juga karena lahan yang selalu diwariskan sehingga lahan tersebut semakin terbagi-bagi menjadi lebih kecil. Luas lahan merupakan modal utama yang digunakan dalam berusahatani sehingga dapat menjadi penentu kemandirian petani dalam menentukan sendiri keputusannya agar dapat mengembangkan usahataninya serta menjaga keberlanjutan usahataninya (Malta, 2016).

\section{Faktor Eksternal}

Faktor Eksternal adalah suatu faktor yang asalnya dari luar diri petani dan menjadi pendukung kemandirian petani (Aminudin, 2014). Berdasarkan pernyataan responden melalui kuesioner dihasilkan sebaran data menurut nilai tengah serta simpangan baku, maka faktor eksternal yang terdapat pada responden adalah sebagai berikut:

Tabel 6. Faktor Eksternal

\begin{tabular}{lllc}
\hline No & Variabel & Kategori & $\begin{array}{c}\text { Persen } \\
(\%)\end{array}$ \\
\hline \multirow{2}{*}{1} & Dukungan & rendah $(<11)$ & $1,8 \%$ \\
& KSM Jaya & sedang $(11-16)$ & $81,5 \%$ \\
& Amanah & tinggi $(>16)$ & $16,7 \%$ \\
\hline \multirow{2}{*}{2} & \multirow{2}{*}{ Ketersediaan } & rendah $(<5)$ & $0 \%$ \\
& Informasi & sedang $(5-6)$ & $7 \%$ \\
\hline \multirow{3}{*}{3} & Ketersediaan & tinggi $(>6)$ & $93 \%$ \\
\hline & Sarana & sedang $(<10)$ & $0 \%$ \\
& Prasarana & tinggi $(>10)$ & $4 \%$ \\
\hline
\end{tabular}

\section{Dukungan KSM Jaya Amanah}

Dukungan KSM Jaya Amanah berada pada kategori sedang. Dukungan dalam penyediaan modal yang dirasakan oleh petani anggota adalah tinggi serta merasakan manfaat yang tinggi. Jumlah modal dari KSM Jaya Amanah memang tidak begitu besar, namun petani merasakan manfaat yang tinggi karena selain mendapat tambahan modal mereka juga merasakan adanya keberkahan 
menggunakan sistem pembiayaan syariah bai' salam. Berbeda dengan hasil penelitian Managanta, dkk (2019) yakni sebagian petani menilai dukungan serta peran kelembagaan untuk bidang permodalan relatif rendah.

Dukungan KSM Jaya Amanah dalam pelatihan/ pendampingan/ penyuluhan, petani anggota merasakan dukungan serta manfaat yang tinggi. KSM Jaya Amanah menyediakan fasilitas pendampingan anggota dengan adanya Saung Ilmu. Sejalan dengan penelitian Aminudin (2014) bahwa dukungan lembaga penyuluhan tergolong baik.

Dukungan dalam pemasaran tidak begitu tinggi karena KSM Jaya Amanah belum bisa menampung semua hasil tani para anggota, terutama untuk komoditas palawija. Dalam pembiayaan syari'ah dengan bai' salam, petani bisa mengembalikan modal dalam bentuk hasil tani. Misalkan modal petani padi yang diajukan sebesar Rp1.000.000, maka petani bisa membayarnya dengan gabah padi seharga Rp1.000.000. Jika hasil panen banyak, sebagiannya akan dikonsumsi pribadi dan sebagian lain ada yang dijual ke KSM Jaya Amanah. Namun untuk palawija, KSM Jaya Amanah belum bisa menerima, akibatnya petani masih menjualnya ke bandar.

\section{Ketersediaan Informasi}

Ketersediaan informasi usahatani tergolong tinggi. Sejalan dengan penelitian Priana (2004) bahwa ketersediaan informasi agroforestri dikategorikan sedang sampai tinggi, petani menyatakan informasi yang ada sudah tersedia serta dapat dijangkau. Informasi yang paling dekat dengan petani adalah bersumber dari sesama petani yang telah berpengalaman dan berhasil dalam kegiatan usahatani. Petani memperoleh informasi dari sesama petani karena mereka merasa sumber informasi tersebut mudah untuk diperoleh dan selalu ada saat dibutuhkan sehingga petani tidak perlu pergi jauh untuk mencari informasi. Kemudian, informasi tersebut menyebar ke petani lain dari mulut ke mulut.

Adapun informasi yang diperoleh yaitu teknik budidaya, harga sarana produksi, harga produk, serta saluran pemasaran. KSM Jaya Amanah berperan dalam memberikan informasi tambahan kepada petani mengenai ilmu pengetahuan baru seperti manajemen keuangan/ permodalan, konsep pembiayaan syariah, teknik budidaya terbaru, penanggulangan hama, dan lain sebagainya. 


\section{Ketersediaan Sarana Prasarana}

Ketersediaan sarana prasarana untuk melakukan usahatani termasuk dalam kategori tinggi. Sarana produksi yang dibutuhkan yakni bibit, pupuk, obatobatan, dan peralatan pertanian. Berbeda dengan penelitian Sinaga (2016) yang menyatakan bahwa ketersediaan sarana produksi petani karet pola swadaya di Desa Kuntu, Kabupaten Kampar masih rendah.

Adapun pembelian sarana prasarana oleh petani umumnya diperoleh dari dalam desa dengan jumlah yang cukup memenuhi kebutuhan petani. Bibit padi biasanya diperoleh dari dalam desa, dan kebanyakan petani membuat bibit sendiri dari hasil panennya sehingga tidak perlu lagi untuk membeli bibit. Pupuk dan obat-obatan juga bisa dibeli di dalam desa, jadi petani tidak perlu untuk pergi jauh-jauh membelinya.

Begitu juga dengan peralatan pertanian yang masih bisa dibeli di desa. Harga sarana dan prasarana tersebut masih mampu dijangkau namun ada juga beberapa yang tidak mampu dijangkau oleh petani, sesuai dengan keuangan petani. KSM Jaya Amanah melakukan pembinaan kepada petani dalam hal penyediaan bibit dan pupuk sendiri melalui program kemandirian bibit dan kemandirian pupuk. Awalnya bibit dan pupuk untuk usahatani dibeli $100 \%$ dari toko, namun kini tidak sepenuhnya karena bisa membuat bibit dan pupuk sendiri dengan arahan dari pengurus KSM Jaya Amanah.

\section{Kemandirian Petani dalam Pengambilan Keputusan Usahatani}

Kemandirian Petani dalam Pengambilan Keputusan Usahatani adalah suatu keadaan petani untuk mampu serta bebas dalam memutuskan kegiatan yang akan dilakukan dalam usahatani.

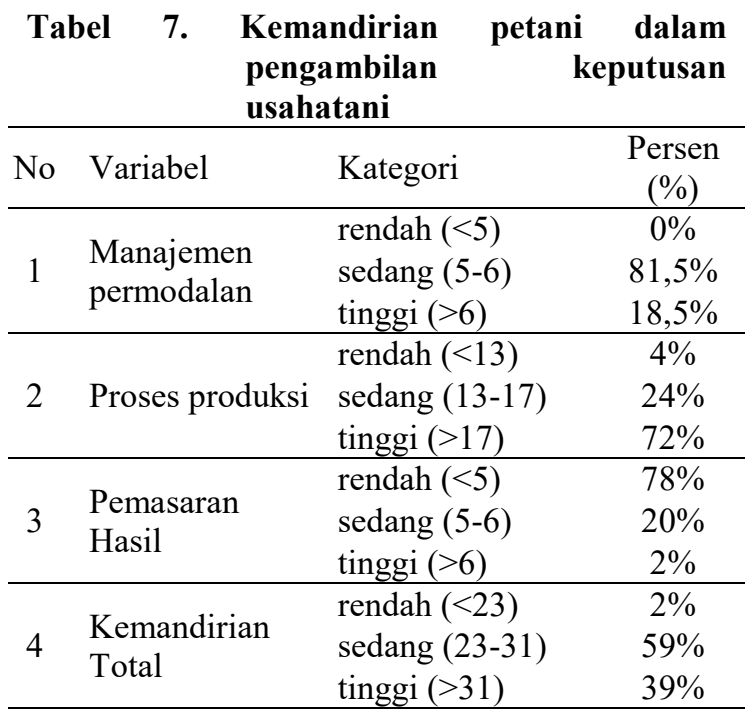

\section{Manajemen Permodalan}

Kemandirian petani dalam pengambilan keputusan manajemen permodalan termasuk dalam kategori sedang. Modal yang digunakan berasal dari KSM Jaya Amanah dan juga dari modal pribadi. Petani anggota sudah 
mulai bisa mengurangi biaya untuk usahatani dengan memanfaatkan pekarangan rumah untuk menurunkan belanja rumah tangga sehingga bisa menabung lebih banyak untuk modal usahatani. Selain itu, terdapat tabungan sukarela di KSM Jaya Amanah yang diarahkan oleh pengurus untuk tabungan keluarga petani anggota.

Penentuan sumber modal dan jumlah modal yang dikeluarkan umumnya diputuskan oleh diri sendiri dan ada yang dibantu oleh keluarga. Beberapa petani sudah mulai melakukan analisis usahatani dengan cara mencatat pemasukan dan pengeluaran, dan ada juga beberapa orang yang mencatat sambil menganalisis untung rugi agar dapat menghindari kerugian di masa mendatang. Berbeda dengan penelitian Malta (2016) bahwa kemandirian petani memutuskan suatu hal mengenai pengelolaan keuangan berada di tingkat rendah yang dikarenakan $83,3 \%$ responden tidak menganalisis usahataninya serta kurang mampu dalam penentuan besarnya pengeluaran dan penerimaan usahatani.

\section{Proses Produksi}

Kemandirian petani dalam pengambilan keputusan proses produksi termasuk dalam kategori tinggi.
Penentuan jenis komoditas yang akan ditanam, sebagian petani mengikuti sesama petani dan ada juga yang dari diri sendiri berdasarkan kebiasaan dan menyesuaikan dengan lahan serta kondisi lingkungan (termasuk pasar). Bantuan orang lain dalam hal pengetahuan pada kegiatan usahatani seperti teknik pengolahan tanah, teknik penanaman, dan teknik pemanenan tidak terlalu dibutuhkan oleh petani dikarenakan mereka sudah menguasai teknik tersebut yang dipelajari atau didapatkan secara turun temurun. Sementara untuk kegiatan pemilihan bibit, pemeliharaan, dan pemberantasan hama penyakit bantuan orang lain dalam hal pengetahuan terkadang dibutuhkan. Bahkan beberapa petani ada yang sangat membutuhkan bantuan pengetahuan dalam kegiatan pemilihan bibit dan pemberantasan hama penyakit. Petani yang berusia muda yang membutuhkan bantuan tersebut dikarenakan masih belum terlalu mengerti dan belum memiliki pengalaman. Berbeda dengan pemberantasan hama dan penyakit, kebanyakan petani membutuhkan bantuan dalam hal pengetahuan karena ilmu mengenai pemberantasan hama dan penyakit selalu berkembang sehingga dibutuhkan informasi mengenai obat 
terbaru yang ampuh mengurangi serangan hama dan penyakit pada tanaman.

\section{Pemasaran Hasil}

Kemandirian petani dalam pengambilan keputusan pemasaran hasil termasuk dalam kategori rendah. Sejalan dengan penelitian Sinaga (2016) bahwa kemandirian petani untuk memutuskan dalam kegiatan pemasaran tergolong masih rendah. Begitu juga dengan penelitian Malta (2016), petani tidak memiliki pilihan lain untuk menjual hasil taninya sehingga masih menjual kepada pedagang pengumpul, juga disebabkan oleh ketidaktahuan petani akan informasi mengenai harga pasar sehingga harga produk ditentukan oleh pedagang pengumpul.

Umumnya petani anggota KSM Jaya Amanah menjual hasil taninya kepada tengkulak atau bandar, komoditas yang dijual biasanya adalah palawija sedangkan padi digunakan untuk mengembalikan modal dari KSM Jaya Amanah dengan sistem tunda serah dan sebagiannya digunakan untuk konsumsi pribadi. Harga jual ditentukan oleh bandar, namun sebenarnya tidak sematamata penentuan harga oleh bandar, petani juga mengetahui harga pasar yang diperoleh dari mulut ke mulut.

\section{Kemandirian Total}

Kemandirian total petani yakni kemandirian petani dalam pengambilan keputusan usahatani termasuk dalam kategori sedang. Artinya, sudah tinggi dari segi manajemen permodalan dan proses produksi, namun masih rendah dari segi pemasaran hasil. Petani masih membutuhkan dorongan dan dukungan dari berbagai pihak seperti pemerintah, lembaga, dan KSM Jaya Amanah. Dorongan dan dukungan yang diberikan akan semakin membantu petani agar dalam pengembangan usahataninya dapat mengatasi permasalahan yang ada. Berbeda dengan hasil penelitian Malta (2016) bahwa kemandirian petani pada Desa Sukaharja Kabupaten Bogor berada pada tingkat rendah baik dalam pengelolaan keuangan, penanganan hasil, maupun pemasaran. Berbeda juga dengan penelitian Sinaga (2016) bahwa tingkat kemandirian dalam pengambilan keputusan usahatani pada petani karet pola swadaya berada pada kategori tinggi.

Faktor-faktor yang Berhubungan dengan Kemandirian Petani dalam Pengambilan Keputusan Usahatani

Uji koefisien korelasi Rank Spearman digunakan untuk melihat hubungan antara faktor internal serta 
faktor eksternal terhadap kemandirian petani dalam pengambilan keputusan usahatani. Uji tersebut dilakukan menggunakan IBM SPSS Statistics 23. Untuk melihat kekuatan hubungan antara dua variabel maka digunakan interpretasi sebagai berikut (Riduwan, 2010):

Tabel 8. Interpretasi Kekuatan Hubungan Antara Dua Variabel

\begin{tabular}{|c|c|c|}
\hline No & $\begin{array}{c}\text { Nilai Koefisien } \\
\text { Korelasi }\end{array}$ & Kekuatan Hubungan \\
\hline 1 & 0,00 & Tidak ada \\
\hline 2 & $0,10-0,20$ & $\begin{array}{l}\text { Sangat rendah/ lemah } \\
\text { sekali }\end{array}$ \\
\hline 3 & $0,21-0,40$ & $\begin{array}{c}\text { Rendah/ lemah tapi } \\
\text { pasti }\end{array}$ \\
\hline 4 & $0,41-0,70$ & Cukup berarti/ sedang \\
\hline 5 & $0,71-0,90$ & Tinggi/ kuat \\
\hline 6 & $0,91-1,00$ & $\begin{array}{l}\text { Sangat tinggi/ kuat } \\
\text { sekali }\end{array}$ \\
\hline 7 & 100 & $\begin{array}{c}\text { Sangat tinggi atau kuat } \\
\text { sekali, dapat dikatakan } \\
\text { sempurna }\end{array}$ \\
\hline
\end{tabular}

Untuk melihat arah hubungan, dilihat dari angka positif $(+)$ atau negatif $(-)$.

- Positif $(+)$ : hubungan antar variabel searah, jika variabel bebas semakin tinggi maka variabel terikat juga semakin tinggi.

- Negatif(-) : hubungan antar variabel tidak searah, jika variabel bebas semakin tinggi maka variabel terikat akan semakin rendah

Koefisien korelasi usia petani dengan kemandirian total adalah 0,457 pada signifikansi $10 \%$ yang berarti menunjukkan hubungan yang cukup berarti karena bernilai positif. Terdapat hubungan positif artinya, semakin tinggi usia petani maka kemandirian dalam pengambilan keputusan usahatani akan semakin tinggi juga. Hubungan jenis kelamin dengan kemandirian total memiliki koefisien korelasi 0,302 pada signifikansi $5 \%$ yang menunjukkan terdapat hubungan yang positif lemah tapi pasti. Artinya, kemandirian dalam pengambilan keputusan usahatani pada petani yang berjenis kelamin laki-laki adalah lebih tinggi.

Koefisiensi korelasi pengalaman usahatani dengan kemandirian total adalah 0,487 pada signifikansi $10 \%$, ini menunjukkan adanya hubungan yang positif serta cukup berarti. Artinya, jika pengalaman berusahatani semakin lama akan menyebabkan semakin tingginya kemandirian petani dalam pengambilan keputusan usahatani.

Nilai koefisien korelasi pendidikan dengan kemandirian petani dalam pengambilan keputusan usahatani adalah $-0,214$ dan tidak berada pada signifikansi $5 \%$ atau 10\%. Maka dapat dikatakan tidak terdapat hubungan antara pendidikan dengan kemandirian petani dalam pengambilan keputusan usahatani. Namun, secara parsial hubungan antara pendidikan terhadap kemandirian dalam 
proses produksi adalah lemah tapi pasti.

Ditunjukkan dengan nilai koefisien korelasi nya yakni $-0,294$ pada signifikansi $5 \%$. Artinya adanya kecenderungan jika pendidikan semakin tinggi maka kemandirian dalam proses produksinya semakin rendah. Sesuai dengan hasil penelitian Priana (2004) bahwa jika tingkat pendidikan formal petani semakin tinggi, maka kemandirian dalam proses produksi cenderung menjadi semakin lemah. Atau dapat dikatakan, tingkat pendidikan tidak memberikan pengaruh yang sangat nyata dalam meningkatkan kemandirian petani.
Nilai koefisien korelasi keaktifan mencari informasi dan luas lahan terhadap kemandirian petani dalam pengambilan keputusan usahatani adalah 0,053 dan 0,036 yakni tergolong sangat rendah. Hal ini bukan berarti tidak terdapat hubungan sama sekali, angka positif menunjukkan adanya hubungan yang positif. Artinya, jika semakin tinggi keaktifan mencari informasi dan semakin luas penguasaan lahan maka akan semakin tinggi juga kemandirian petani dalam memutuskan kegiatan usahatani. Akan tetapi hubungan tersebut tidak terlalu erat sehingga secara statistik dikatakan tidak nyata.

Tabel 9. Faktor-faktor yang Berhubungan dengan Kemandirian Petani dalam Pengambilan Keputusan Usahatani

\begin{tabular}{|c|c|c|c|c|c|}
\hline \multirow[b]{2}{*}{ No } & \multirow[b]{2}{*}{ Peubah } & \multicolumn{3}{|c|}{ Kemandirian Petani dalam: } & \multirow[b]{2}{*}{$\begin{array}{l}\text { Total } \\
(Y .1)\end{array}$} \\
\hline & & $\begin{array}{c}\text { Manajemen } \\
\text { Permodalan } \\
(\mathrm{Y} 1.1)\end{array}$ & $\begin{array}{c}\text { Proses } \\
\text { Produksi } \\
(\mathrm{Y} 1.2) \\
\end{array}$ & $\begin{array}{c}\text { Pemasaran } \\
\text { Hasil (Y1.3) }\end{array}$ & \\
\hline \multicolumn{6}{|c|}{ Faktor Internal: } \\
\hline 1 & Usia (X1.1) & 0.239 & $0.406 * *$ & -0.016 & $0.457 * *$ \\
\hline 2 & Jenis Kelamin (X1.2) & $0.397 * *$ & 0.16 & 0.209 & $0.302 *$ \\
\hline 3 & Pendidikan (X1.3) & 0.158 & $-0.294 *$ & -0.162 & -0.214 \\
\hline 4 & $\begin{array}{l}\text { Jumlah Tanggungan Keluarga } \\
\text { (X1.4) }\end{array}$ & -0.102 & -0.153 & -0.025 & -0.068 \\
\hline 5 & Pengalaman Usahatani (X1.5) & $0.357 * *$ & $0.427 * *$ & -0.098 & $0.487 * *$ \\
\hline 6 & Keakifan Mencari Informasi (X1.6) & 0.157 & 0.001 & -0.008 & 0.053 \\
\hline 7 & Luas Lahan (X1.7) & -0.085 & 0.013 & 0.191 & 0.036 \\
\hline \multicolumn{6}{|c|}{ Fakor Eksternal } \\
\hline 1 & Dukungan KSM Jaya Amanah & $0.286 *$ & 0.081 & -0.009 & 0.177 \\
\hline 2 & Ketersediaan Informasi & 0.095 & $0.291 *$ & -0.132 & $0.336 *$ \\
\hline 3 & Ketersediaan Sarana Prasarana & 0.1 & $0.455 * *$ & 0.091 & $0.473 * *$ \\
\hline
\end{tabular}

Selanjutnya untuk faktor eksternal, ketersediaan informasi dengan kemandirian memiliki koefisien korelasi 0,336 pada signifikansi $5 \%$ yang menunjukkan bahwa terdapat hubungan yang positif lemah tapi pasti. Artinya, semakin tinggi tingkat ketersediaan informasi maka kemandirian petani 
dalam pengambilan keputusan usahatani semakin tinggi juga. Didukung oleh hasil penelitian Ningsih mengungkapkan, petani yang terpapar dengan informasi akan meningkatkan kualitas petani sehingga akan menjadi faktor penting dalam mewujudkan petani yang mandiri. Selanjutnya koefisien korelasi antara ketersediaan sarana prasarana dengan kemandirian adalah 0,473 pada signifikansi $10 \%$ yang memperlihatkan bahwa terdapat hubungan positif yang cukup berarti. Artinya, jika tingkat ketersediaan sarana prasarana semakin tinggi maka semakin tinggi juga kemandirian petani dalam pengambilan keputusan usahatani.

Tidak terdapat hubungan antara dukungan KSM Jaya Amanah dengan kemandirian petani dalam pengambilan keputusan usahatani. Dapat dilihat dari koefisien korelasi nya yakni 0,177 dan tidak berada pada signifikansi $5 \%$ atau $10 \%$. Namun secara parsial, dukungan KSM Jaya Amanah memiliki hubungan yang lemah tapi pasti dengan kemandirian petani dalam manjemen permodalan. Dapat dilihat dari koefisien korelasi nya yakni 0,286 pada signifikansi $5 \%$. Artinya semakin tinggi dukungan KSM Jaya Amanah maka semakin tinggi kemandirian petani dalam manajemen permodalan. Melalui wawancara, umumnya responden merasakan bantuan yang diperoleh dari KSM Jaya Amanah dapat membantu dalam permodalan usahatani. Selain itu, petani anggota juga sering mengikuti saung ilmu yang diadakan satu kali dalam 1 bulan dimana melalui saung ilmu mereka banyak mendapatkan ilmu mengenai manjemen keuangan, teknik berusahatani, bahkan keagamaan. Selain mengikuti saung ilmu yang diadakan satu kali sebulan, banyak juga petani anggota yang sering berkunjung setiap harinya untuk berdiskusi dan bertukar pikiran dengan petani lainnya dan juga dengan pengurus KSM Jaya Amanah.

\section{KESIMPULAN DAN SARAN}

\section{Kesimpulan}

Kemandirian petani anggota KSM Jaya Amanah dalam pengambilan keputusan usahatani berada pada kategori sedang sampai tinggi. Petani anggota telah mandiri dari segi manajemen permodalan dan proses produksi namun kurang mandiri dari segi pemasaran hasil. Faktor-faktor yang berhubungan dengan kemandirian petani dalam pengambilan keputusan usahatani adalah: usia, jenis kelamin, pengalaman berusahatani, 
ketersediaan informasi, dan ketersediaan sarana dan prasarana.

\section{Saran}

Dukungan dari berbagai pihak baik pemerintah, akademisi maupun KSM Jaya Amanah sendiri masih diperlukan dalam menjaga petani agar tetap mandiri dalam manajemen permodalan dan proses produksi serta meningkatkan kemandirian petani dalam pemasaran hasil melalui pendampingan, penyuluhan, dan pelatihan mulai dari penyediaan sarana produksi hingga pemasaran hasil usahatani.

\section{DAFTAR PUSTAKA}

Aminudin. (2014). Tingkat Kemandirian Petani dalam Pengambilan Keputusan Usahatani Tanaman Pangan di Kabupaten Bogor. [Tesis].

Arikunto, Suharsimi. (2012). Prosedur Penelitian. Jakarta: Rineka Cipta.

Badan Pusat Statistik. Produk Domestik Bruto Indonesia Triwulan 20152019.

Febriana, R. (2013). Pengaruh kemitraan pabrik gula karangsuwung kabupaten cirebon terhadap tingkat kesejahteraan petani tebu. [Skripsi].

Ibrahim, J. T. (2001). Kajian Reorientasi Penyuluhan Pertanian Ke Arah Pemenuhan Kebutuhan Petani di Propinsi Jawa Timur. Disertasi. Sekolah Pasca-sarjana. Institut Pertanian Bogor.

Khasanah, Umrotul. (2010). Manajemen Zakat Modern. Malang: UINMALIKI PRESS.
Malta. (2016). Faktor-faktor yang Berhubungan dengan Kemandirian Petani dalam Pengambilan Keputusan untuk Keberlanjutan Usahatani (Kasus Petani di Desa Sukaharja - Kabupaten Bogor). Jurnal Sosiohumaniora.

Musafiri, I. (2016). Effects of Population Growth on Smallholder Farmers' Productivity and Consumption in Rwanda: A Long-term Analysis. Asian Journal of Agricultural Extension, Economics \& Sociology, 12(4): 1-11. DOI: 10.9734/AJAEES/2016/27693.

Nasution, Z. (2016). Model Pembiayaan Syariah untuk Sektor Pertanian. IQTISHADIA: Jurnal Ekonomi \& Perbankan Syariah, 3(2), 324. https://doi.org/10.19105/iqtishadia. v3i2.1081

Ningsih, K. (2011). Pengembangan Sumberdaya Manusia Petani. Jurnal Pertanian UIM, 2 (1): 3445.

Lestari, M. (2011). Dinamika Kelompok dan Kemandirian Anggota Kelompok Tani dalam Berusahatani di Kecamatan Poncowarno Kabupaten Kebumen Propinsi Jawa Tengah.

Priana, M. (2004). Identifikasi Faktorfaktor yang Berhubungan dengan Tingkat Kemandirian Petani dalam Melakukan Usaha Agroforestri (Kasus Usaha Agroforestri Pohpohan di Hutan Pinus dan Damar Desa Tamansari Kecamatan Tamansari Kabupaten Bogor). [Tesis].

Ratnasari, T., Sumarsih, E., \& Heryadi, D.Y. (2012). Pengaruh Tingkat Pendidikan Terhadap Persepsi Masyarakat Tentang Sayuran Organik. Jurnal Pertanian Universitas Siliwangi, 2 (1): 17-30.

Riduwan. (2010). Skala Pengukuran Variabel-variabel Penelitian. 
Bandung: Alfabeta

Saragih, F. H. (2017). Pembiayaan Syariah Sektor Pertanian. Jurnal Agrica, $\quad 10(2), \quad 112$. https://doi.org/10.31289/agrica.v10i 2.1458

Sudalmi, E. S. (2009). Analisis penggunaan tenaga kerja pertanian pada usahatani padi sawah. Jurnal Inovasi Pertanian. 8 (1) : 8-19.
Widiyawati, R.F. (2017). Analisis Keterkaitan Sektor Pertanian dan Pengaruhnya Terhadap Perekonomian Indonesia (Analisis Input Output). Jurnal Economica. 